\title{
THE EFFECTS OF GAMMA IRRADIATION AND SOMACLONAL VARIATION ON MORPHOLOGY VARIATION OF MUTANT RODENT TUBER
}

\section{(Typhonium flagelliforme Lodd.) LINES}

\author{
Nesti F. Sianipar ${ }^{\star 1}$, Ragapadmi Purnamaningsih ${ }^{2}$, Ireng Darwati ${ }^{3}$, Danny Laurent ${ }^{4}$, \\ and Chelen ${ }^{4}$ \\ ${ }^{1,4}$ Department of Biology, Faculty of Science and Mathematics, Universitas Pelita Harapan, \\ M.H. Thamrin Boulevard 1100 Lippo Village, Indonesia \\ 2 Balai Besar Penelitian dan Pengembangan Bioteknologi dan Sumberdaya Genetik Pertanian, \\ Jl. Tentera Pelajar 3A Bogor 16111 \\ ${ }^{3}$ Balai Penelitian Tanaman Obat dan Aromatik, Jl. Tentera Pelajar 3 Bogor 16111 \\ * To Whom all correspondence should be addressed :Dr. Nesti F. Sianipar \\ Email : nestipro@yahoo.com
}

\begin{abstract}
Rodent tuber (Typhonium flagelliforme Lodd.) is an Indonesian plant with high medicinal potential as anti-cancer. This plant has a low genetic variation in Indonesia. Gamma irradiation can be used to increase genetic variation. This research aimed to explore the effects of gamma irradiation and somaclonal variation on several mutant rodent tuber lines. Six somatic cell populations, which were treated by 6 Gy of gamma irradiation, were successfully regenerated into plantlets. Six mutant lines had been sub cultured into second and third generations by using optimal regeneration media (MS0 supplemented with $0.5 \mathrm{mg} / \mathrm{L}$ BAP and 1 mg/L NAA). Rooting of in vitro plantlets had been done by using optimal rooting media MS0 supplemented with $0 \mathrm{mg} / \mathrm{L}$ NAA and $0.5 \mathrm{mg} / \mathrm{L} \mathrm{NAA}$ ). Plantlets with good roots were acclimatized and transferred into greenhouse. The morphology of first generation mutant in greenhouse (M1) were characterized and analyzed by using descriptive statistical method. The observed morphological characters including plant height, shoot number, leaf number, and leaf area. A hundred and seventy five (175) mutant lines were obtained on the third generation (MV3) from five somatic cell populations. Mutant line 6-3-x has the highest mean number of shoots, which was 4.62 shoots. Percentage of plant alive after acclimatization in the greenhouse was $78 \%$. Out of $37 \mathrm{M} 1$ mutant lines, morphologically diverse lines were observed with the highest plant height increase: $15.5 \mathrm{~cm}$ on 6-2-4-1 mutant line, the highest plant shoots increase: 5 shoots on 6-6-7-8 mutant line, the highest leaf number increase: 17 leaves on 6-6-7-8 mutant line, and the highest leaf area increase: $47.24 \mathrm{~cm}^{2}$ on 6-2-5-2 mutant line. In conclusion, gamma irradiation and somaclonal variation could increase genetic variation of mutant rodent tuber lines as shown by morphological data.
\end{abstract}

Keywords : Thyphonium flagelliforme, Gamma-Irradiation Somaclonal-Variation, Morphology-Variation

\section{INTRODUCTION}

Rodent tuber is an Indonesian plant commonly found in Java island and grows well at 1$300 \mathrm{~m}$ altitude above the sea (Essai, 1985). Rodent tuber is a medicinal plant. Several countries in Asia has been using the plant to treat cancer (Chan et al., 2005), such as liver cancer (Lai et al., 2008), breast cancer, intestinal cancer, prostate cancer, cervix cancer (Syahid, 2008), and leukemia (Mohan et al., 2010). Sianipar, Maarisit and Valencia (2013) had reported the toxicity effect rodent tuber's extract and hexane fraction on Artemia salina.

Rodent tuber has low genetic variation because the plant commonly propagates vegetatively through tuber separation (Syahid \& Kristina, 2007). Gamma irradiation is one of methods to increase genetic variation. Gamma irradiation is one of the most commonly used mutation breeding method (Natawijaya et al., 2009) because it could change the chemical reaction in plant cells and could cause chromosomal aberration in plants (Achrom et al.,

ISSN 2413-0877 (C) 2015 The Authors.

Published by KnowledgeE Publishing Services This is an open access article under the CC BY-NC-ND license (http://creativecommons.org/licenses/by-nc-nd/4.0)

Selection and Peer-review under responsibility of the 3rd ICBS-2013

Doi http://dx.doi.org/10.18502/kls.v2i1.236 
2011). Genetical changes caused by mutation can also cause changes in secondary metabolites produced by plants (Kovács \& Keresztes, 2002). Mutated genes will change and produce different variation of proteins or enzymes (Karp, 2008).

Rodent tuber had been successfully propagated through in vitro techniques in Murashige Skoog (MS) medium with optimal concentration of NAA $1 \mathrm{mg} / \mathrm{l}$ and BAP $0.5 \mathrm{mg} / \mathrm{L}$ (Sianipar et al., 2011). In vitro rodent tuber plants had been successfully irradiated with gamma irradiation and mutant rodent tuber plantlets had been obtained. Mutant in vitro rodent tubers showed difference in height and number of shoots compared to control plantet (Sianipar et al., 2013). Genetic variation selection of first generation field mutant rodent tuber (M1) should be done to screen mutants with high genetic variation. This research aimed to know the effect of gamma irradiation and somaclonal variation to morphological variation of several different lines of mutant rodent tubers.

\section{MATERIAL AND METHODS}

\section{Propagation of Mutant Plants}

Eight weeks old in vitro mutant plantlets of rodent tuber were subcultured to optimal propagation medium, which is Murashige Skoog (MS) medium supplemented with $1 \mathrm{mg} / \mathrm{l}$ NAA and $0.5 \mathrm{mg} / \mathrm{LBAP}$. After ten weeks of in vitro culture, mutant plantlets were acclimated in acclimatization medium of sekam : compost (1:1) for four weeks and then moved to greenhouse.

\section{Rooting of Mutant Rodent Tuber Plantlets}

Rooting of mutant rodent tuber plantlets was done in MSO medium supplemented with coconut water, increasing NAA concentration $(0 ; 0.5 ; 1 ; 1.5 \mathrm{mg} / \mathrm{l})$ and combination $0.5 \mathrm{mg} / \mathrm{l}$ BAP with increasing NAA concentration ( 1 and $1.5 \mathrm{mg} / \mathrm{l})$. Rooting percentage of the plantlets was observed in the eight week of culture.

\section{Acclimatization of Mutant Rodent Tuber Plantlet}

Acclimatization of mutant rodent tuber plantlets was done in Laboratory of Advance Biology Universitas Pelita Harapan. Mutant plantlets were taken out of culture bottles, washed with flowing water and sunk in bacteriside fungiside $(0.25$ gram each in $200 \mathrm{ml}$ of water) solution for 15 minutes. Plantlets were plantlet into medium containing sekam and compost. Viability percentage of plantlets was observed for four weeks. Living plantlets were then moved to greenhouse at BB-Biogen and plantler in soil medium. Viability percentage of the acclimated plantlets was observed for four weeks.

\section{Morphological Characterization of Mutant Rodent Tuber}

The morphological characters of mutant rodent tuber observed were leaf surfaces, plant height measured from above the soil to the highest leaf, the number of leafs per plant, and the number of shoots per plants. Morphological characters were observed every two weeks for eight weeks. 


\section{RESULT AND DISCUSSION}

\section{Propagation of Mutant Plants In Vitro Rodent Tuber}

Callus of rodent tuber were irradiated with gamma light at 6 gy dose. The in vitro mutant calli were propagated and regenerated in MS medium with $1 \mathrm{mg} / \mathrm{l} \mathrm{NAA}$ and $0.5 \mathrm{mg} / \mathrm{l} \mathrm{BAP}$. This medium was the optimal medium for propagation of in vitro rodent tuber Bogor cultivar (Sianipar et al., 2013). Second and third generation mutant were obtained through in vitro culture in optimal medium. Mean number of shoots of third generation mutant rodent tuber obtained from in vitro culture were shown for each line in Table 1.

Table 1. Regeneration of Third Generation Mutant In Vitro Rodent Tuber

\begin{tabular}{cccccc}
\hline Klon & Replikasi (n) & Rataan & StDev & Mean \pm StDev & Std Error \\
\hline $6-1-\mathrm{x}$ & 8 & 3,25 & 1,28 & $3,25 \pm 1,28$ & 0,45 \\
$6-2-\mathrm{x}$ & 10 & 4,30 & 3,30 & $4,30 \pm 3,30$ & 1,04 \\
$6-3-\mathrm{x}$ & 8 & 4,62 & 3,81 & $4,62 \pm 3,81$ & 1,34 \\
$6-6-\mathrm{x}$ & 16 & 4,31 & 3,68 & $4,31 \pm 3,68$ & 0,92 \\
$6-7-\mathrm{x}$ & 3 & 4,00 & 4,35 & $4,00 \pm 4,35$ & 2,51 \\
\hline
\end{tabular}

Compared to the other mutant lines, mutant rodent tuber M6/3-x line showed the highest mean number of shoots, which was 4.62 shoots. Mutant line M6/7-x showed the lowest mean number of shoots, which was 3.25 shoots. Each line had different variation of shoots number as shown in standard deviation (Table 1). After ten weeks of culture, in vitro plantlets were sub cultured into new medium through tuber separation (Figure 1).

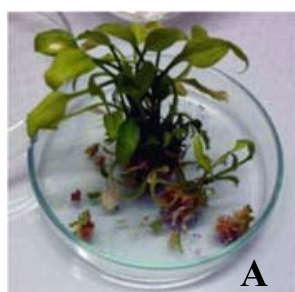

A

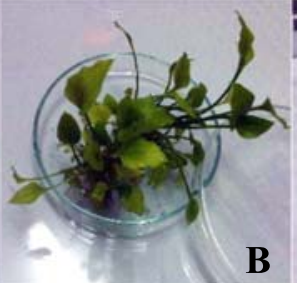

B

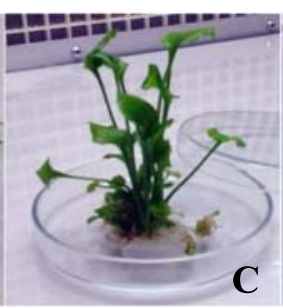

C

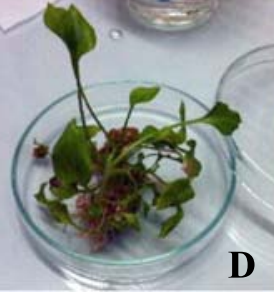

D

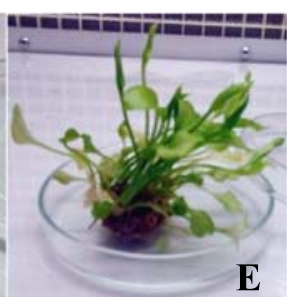

$\mathbf{E}$

Figure 1. Subculture of Third Generation Mutant Rodent Tuber

A: Mutan- 6/1-4-2; B: Mutan-6/2-6-3; C: Mutan-6/3-3-3; D: Mutan-6/6-1-6; E: Mutan-6/7$1-6$

In vitro irradiated calli of rodent tuber showed the ability to regenerage and form plantlets up to the third generation. Number of shoots obtained showed the ability of the mutant plantlets to survive and reproduce vegetatively. Gamma irradiation in 5-15 gy dose in nilam plant affected positively on the growth of nilan plant (Kadir, 2011a) Gamma irradiation of ginger on 7.5 and 12.5 gy could induce the growth of leafs, shoots, and roots of ginger plant (Devy \& Sastra, 2006). The plant tissue of Anthurium which was irradiated by gamma light on 5 gy dose showed good response in regeneration and callus induction (Puchooan \& Sookun, 2003). The use of mutagen at high dose could give several somatic effects on mutated plants (Pucchoa \& Sookun, 2003). Gamma irradiated rice mutant showed decrease in shoots number after the addition of polyethylene glycol (PEG) (Kadir, 2011b).

\section{Media Optimation and rooting induction Mutant Rodent Tuber Plantlet}

In vitro rooting had been done with six treatments of growth regulators (Figure 2). Four out of six treatments used were able to induce roots in mutant rodent tubers, which were 0 $\mathrm{mg} / \mathrm{l}$ 
NAA, $0.5 \mathrm{mg} / \mathrm{NAA}, 0.5 \mathrm{mg} / \mathrm{BAP}+1 \mathrm{mg} / \mathrm{NAA}$, and $0.5 \mathrm{mg} / \mathrm{l} \mathrm{BAP}+1 / 5 \mathrm{mg} / \mathrm{l} \mathrm{NAA}$.

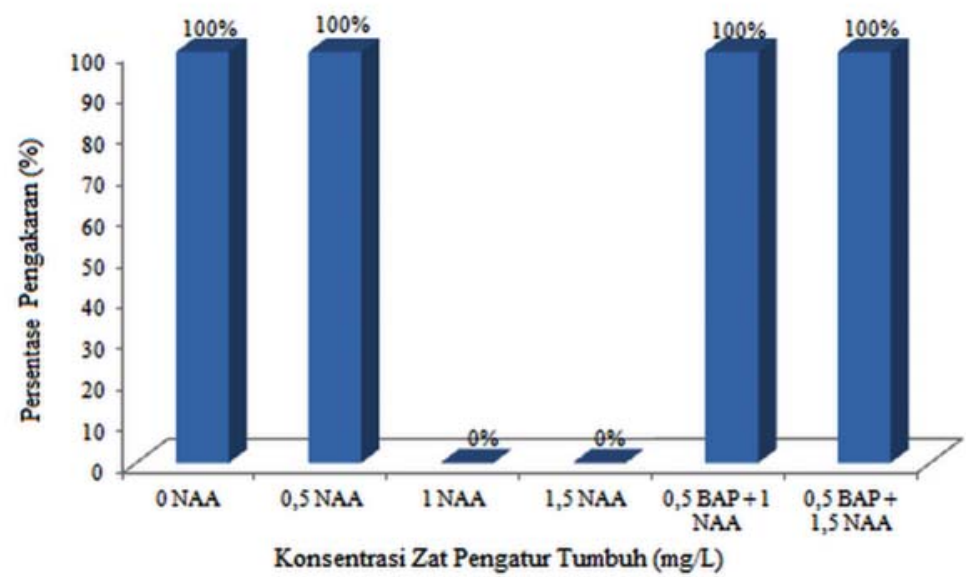

Figure 2. Rooting Percentage of Rodent Tuber Mutant with NAA and BAP

The growth regulator auxin had been known to have several effects on plant's root, which were elongation of root, proliferation of root cells, and differentiation of root cells at certain concentration. High concentration of auxin might inhibit the elongation of root cells (Teale et al., 2005). Rooting data showed decrease in rooting percentage as opposed to the increase of NAA concentration (Figure 2). This data indicated high concentration of endogenous auxin in mutant rodent tubers.

Ratio of auxin and cytokinin had been known to affect the morphogenesis of root in tissue culture (Teale et al., 2005). The use of NAA and BA combination in this research was more effective than high concentration of NAA alone (Figure 2). Combination of growth regulator BAP and IBA, and the addition of charcoal had also been proven effective in rotting of Dendrobium plant (Khatun et al., 2010).

\section{Acclimatization of mutant rodent tuber plantlets}

Acclimatization of mutant rodent tuber plantlets was done for four weeks. Total clones of mutant acclimated were 95 clones. Viability percentage of acclimatization was $66 \%$ on week four (Figure 3).

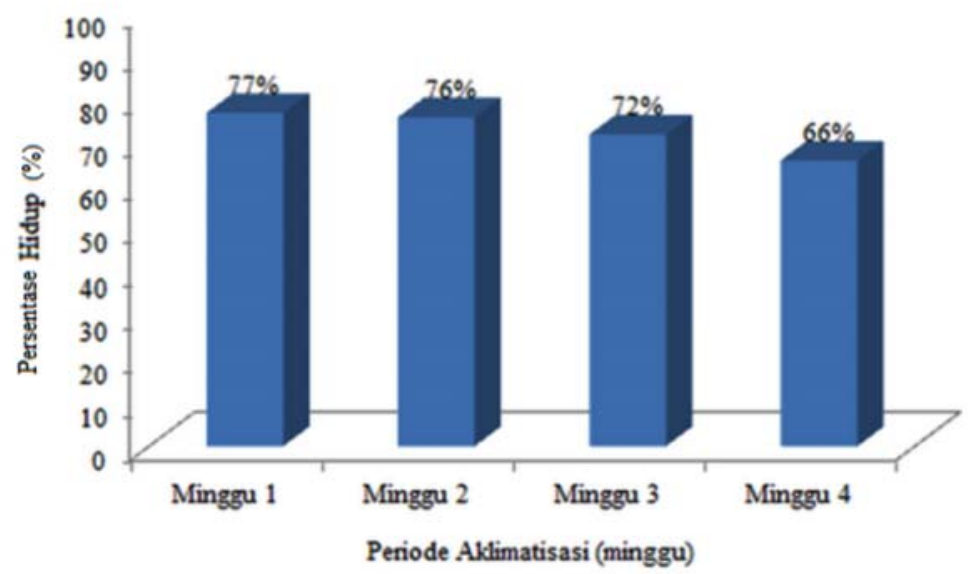

Figure 3. Viability Percentage of Mutant Rodent Tuber Plantlets

Figure 3 showed the development of mutant rodent tuber during acclimatization period. Several shoots of mutant rodent tuber died during the first week of acclimatization. Some 
others survived up to week four.

Acclimatization of in vitro plantlets was affected by several factors, such as acclimatization media (Mishra \& Ansari, 2011), light intensity, and moisture (Hazarika, 2003). The viability percentage obtained in this research $(66 \%)$ was lower than viability percentage of Malaysian rodent tuber, which was $90 \%$ (Nobakht, Kadir \& Stanslas, 2009). This difference was probably due to two factors. The first factor was genetic changes of mutant rodent tuber. Genetic changes that had occurred in mutant rodent tuber might render mutant rodent tuber vulnerable to ex vitro conditions. The second was the difference in acclimatization media used in the experiment. Nobakht et al. (2009) used peatmoss:perlite:vermiculite (3:1:1) media for acclimatization.

Acclimated plantlets were moved to greenhouse after acclimatization. Fourty seven clones were observed for post-acclimatization observation in the greenhouse. The viability percentage obtained post-acclimamtization was 78\% (Figure 4 and Figure 5). Acclimatization in general has successfully removed the weaknesses of plantlets due to in vitro culture condition, such as dependence to high moisture, vulnerability to high light intensity, and vulnerability to microbes (Posposilova, 1999).

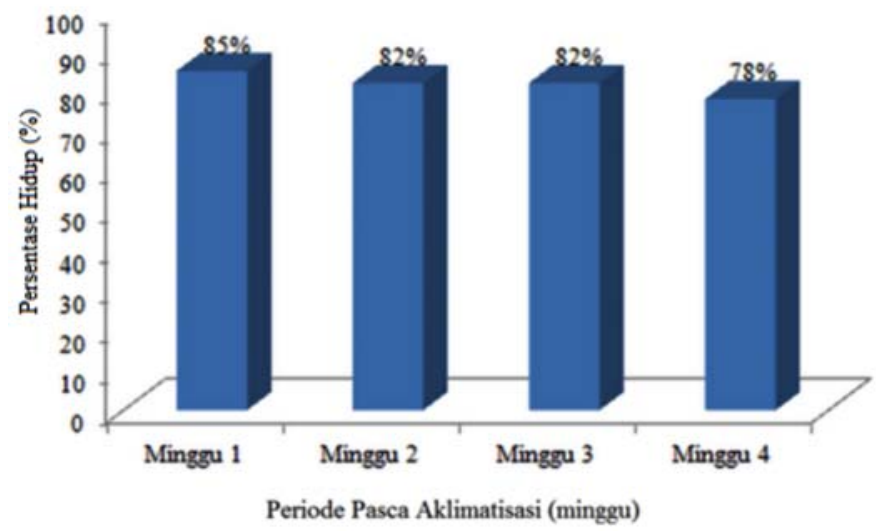

Figure 4. Post-acclimatization viability percentage of mutant rodent tuber

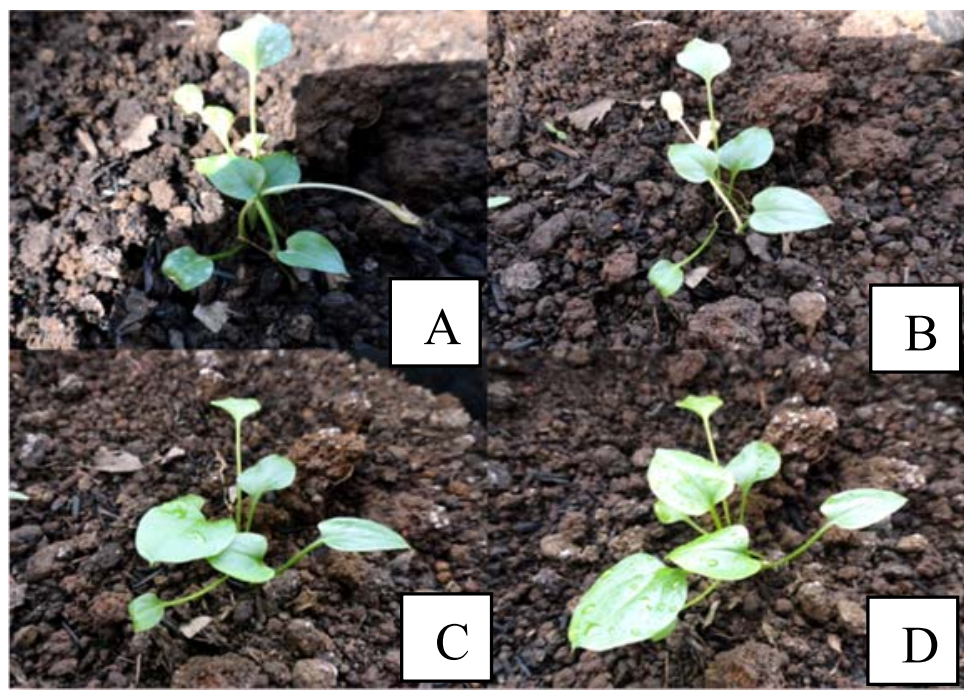

Figure 5. Post-acclimatization mutant rodent tuber plant Plant age (A) 1 week, (B) 2 week, (C) 3 week, (D) 4 week 


\section{Morphological characterization on Rodent Tuber Mutan plantet}

Morphological characterss of rodent tuber mutants had been observed in greenhouse of BB-Biogen. Characterization was done to 37 mutant lines of rodent tuber. Morphological characters obtained in general were variable (Table 2). High standard deviation observed between mutant lines in comparison to control. Mutation through gamma irradiation and somaclonal variation had successfully cause higher variation in morphology of mutant rodent tuber lines. Gamma irradiation caused changes in genome, chromosome, gene, and organelle (Qosim, 2006)

The highest increase in leaf area and leaf circumference was observed in mutant line 69-7, which were $47.41 \mathrm{~cm}^{2}$ and $15.25 \mathrm{~cm}$. The highest plant height increase was observed in mutant lines 6-2-4-1 and 6-9-3 which was $15.50 \mathrm{~cm}$. The highest increase in number of shoots was observed in mutant line 6-6-7-8 with 5 shoots increase. The highest increase in number of leaves was 17 leaves, observed in mutant line 6-6-7-8.

Morphological characters observed in this research were significance agronomically. Leaf area is important to photosynthesis (Stampar et al., 1999), plant height is important for light exposure (Aarsen, 1995), number of leaves and shoots are linked to biomass of plant. Morphologically selected mutants should have good agronomy traits.

Morphological traits of mutant rodent tuber lines had shown the uniqueness of each mutant lines. Mutant lines 6-1-1-1 for example had high increase in all of the parameters observed. Mutant lines 6-6-7-8 had high increase in number of leaves, but the leaf area and circumference were small. Mutant line 6-3-3-10 had low increase in shoot number, but high increase on the leaf area and circumference. Mutant line 6-3-3-5 had low increase in all of the observed parameters.

The uniqueness of each mutant lines (Table 2) indicated a random fashion of genetic changes, which were most likely due to gamma irradiation and somaclonal variation. The random changes in the genome because of gamma irradiation had also been shown in coconut mutants (Rohani et al., 2012). Several other researches had shown changes in morphological characters due to gamma irradiation, for example in mutant sugarcane (Khan et al., 2000), Artemisia (Purnamaningsih et al., 2011), and Phalaenopsis amabilis (L.) Bl. (Sulistianingsih et al., 2006).

\section{CONCLUSION}

In conclusion, in vitro rodent tuber mutant M6/3-x had the highest mean number of shoots, which were 4,62 shoots. Acclimatization of in vitro rodent tuber plantlets was successfully done to 95 clones with $66 \%$ acclimatization viability percentage. Morphological characters obtained were variable, based on leaf area increase, leaf circumference increase, plant height increase, number of leaves, and number of shoots data. Mutant line 6-1-1-1 was a superior mutant based on the observed morphological characters.

\section{ACKNOWLWDGEMENT}

This work was funded by DIKTI through Hibah Bersaing Project in 2013. The authors would like to thank Directorate General of Hinger Education, Ministry of National Education, Indonesia. 
Table 2. Morphological Characters of Mutant Rodent Tubers

\begin{tabular}{|c|c|c|c|c|c|c|}
\hline No & $\begin{array}{c}\text { Mutant } \\
\text { Lines }\end{array}$ & $\begin{array}{c}\Delta \text { Leaf } \\
\text { Area }\left(\mathrm{cm}^{2}\right)\end{array}$ & $\begin{array}{c}\Delta \text { Leaf } \\
\text { Circumferece }(\mathrm{cm})\end{array}$ & $\begin{array}{c}\Delta \text { Plant } \\
\text { Height }(\mathrm{cm})\end{array}$ & $\begin{array}{l}\Delta \text { Number } \\
\text { of Shoots }\end{array}$ & $\begin{array}{l}\Delta \text { Number } \\
\text { of Leaves }\end{array}$ \\
\hline 1 & $6-3-3-6$ & 17,08 & 8,64 & 12,80 & 3 & 8 \\
\hline 2 & $6-2-8-1$ & 8,01 & 7,54 & 8,00 & 0 & 5 \\
\hline 3 & $6-6-7-8$ & 5,34 & 4,40 & 6,00 & 5 & 17 \\
\hline 4 & $6-6-1-9$ & 25,18 & 11,15 & 14,00 & 2 & 15 \\
\hline 5 & $6-2-5-2$ & 43,35 & 14,61 & 12,50 & 0 & 5 \\
\hline 6 & $6-9-4$ & 17,67 & 7,07 & 9,20 & 1 & 5 \\
\hline 7 & $6-2-3$ & 19,44 & 7,54 & 12,50 & 1 & 9 \\
\hline 8 & $6-9-3$ & 44,00 & 12,25 & 15,50 & 1 & 7 \\
\hline 9 & $6-9-7$ & 47,41 & 15,24 & 14,00 & 2 & 9 \\
\hline 10 & $6-9-5$ & 3,22 & 0,31 & 4,50 & 0 & 1 \\
\hline 11 & $6-2-6(3)$ & 17,40 & 6,75 & 11,00 & 0 & 4 \\
\hline 12 & $6-1-6-1$ & 2,145 & 1,41 & 3,50 & 1 & 4 \\
\hline 13 & $6-9-1$ & 40,26 & 10,37 & 12,00 & 3 & 13 \\
\hline 14 & $6-2-1$ & 15,32 & 11,00 & 6,50 & 0 & 6 \\
\hline 15 & $6-3-2-1$ & 36,73 & 17,28 & 11,40 & 0 & 9 \\
\hline 16 & $6-2-8-2$ & 14,96 & 6,75 & 11,50 & 1 & 2 \\
\hline 17 & $6-2-2-4$ & 3,22 & 3,61 & 0,50 & 0 & 3 \\
\hline 18 & $6-6-3-6$ & 19,41 & 5,97 & 11,50 & 0 & 8 \\
\hline 19 & $6-2-4-1$ & 26,47 & 11,31 & 15,50 & 0 & 1 \\
\hline 20 & $6-3-2-3$ & 9,42 & 11,00 & 7,00 & 3 & 10 \\
\hline 21 & $6-1-2$ & 38,10 & 9,58 & 11,10 & 2 & 6 \\
\hline 22 & $6-1-2$ & 26,32 & 7,85 & 10,50 & 3 & 7 \\
\hline 23 & $6-1-3-3$ & 11,98 & 6,28 & 6,50 & 4 & 16 \\
\hline 24 & $6-2-2-8$ & 17,00 & 9,11 & 8,50 & 0 & 3 \\
\hline 25 & $6-2-1-2$ & 13,51 & 6,75 & 9,00 & 1 & 10 \\
\hline 26 & $6-3-3-5$ & 5,50 & 4,71 & 2,50 & 0 & 3 \\
\hline 27 & $6-1-1-1$ & 22,07 & 8,95 & 11,50 & 4 & 11 \\
\hline 28 & $6-1-1-4$ & 6,96 & 6,28 & 5,00 & 0 & 2 \\
\hline 29 & $6-1-3-4$ & 21,60 & 8,64 & 10,20 & 0 & 9 \\
\hline 30 & $6-1-1-2$ & 28,91 & 9,74 & 10,60 & 1 & 5 \\
\hline 31 & $6-1-1-9$ & 23,76 & 10,68 & 13,00 & 2 & 8 \\
\hline 32 & $6-2-6-2$ & 16,26 & 7,85 & 9,10 & 0 & 3 \\
\hline 33 & $6-2-13$ & 11,98 & 7,85 & 8,50 & 2 & 10 \\
\hline 34 & $6-3-3-10$ & 26,40 & 11,00 & 12,80 & 0 & 1 \\
\hline 35 & $6-6-3-4$ & 3,14 & 3,45 & 1,70 & 0 & 0 \\
\hline 36 & $6-6-3-7$ & 3,14 & 6,28 & 2,20 & 1 & 3 \\
\hline \multirow[t]{3}{*}{37} & $6-1-1-6$ & 16,50 & 10,21 & 10,50 & 1 & 9 \\
\hline & $\begin{array}{l}\text { Mutant } \\
\text { Mean }\end{array}$ & $\begin{array}{c}19,17 \pm \\
12,57\end{array}$ & $8,36 \pm 3,55$ & $9,25 \pm 3,94$ & $1,18 \pm 1,39$ & $6,67 \pm 4,30$ \\
\hline & $\begin{array}{l}\text { Control } \\
\text { Mean }\end{array}$ & $\begin{array}{c}10,03 \pm \\
8,07\end{array}$ & $3,55 \pm 3,20$ & $7,4 \pm 1,92$ & $0,00 \pm 0,00$ & $1,60 \pm 2,07$ \\
\hline
\end{tabular}

Mean of control was obtained from 5 replication. Pertambahan variabel dihitung dengan mengurangi nilai variabel pada pengamatan keempat (minggu 8) dan pengamatan pertama (minggu 1). Ä sign on the table showed the increase of each parameter. The increases of each parameter were calculated by substracting data of the eight week of observation and the first week of observation. 


\section{REFERENCES}

Achrom, M., Ruhiyat, D. \& Sunarto. 2012. Pengaruh iradiasi sinar gamma terhadap presentase umbi bawang merah layak jual. Balai Uji Terap Teknik dan Metode Karantina Pertanian.

Aarsen, L.W. 1995. Hyphotheses for the evolution of apical dominance in plants: implications for the interpretation of overcompensation. Oikos 74(1): 149-156.

Chan, L.K., Koh, W.Y., and Tengku-Muhammad, S. 2005. Comparison of Cytotoxic Activities between in Vitro and Field Grown Plants of Typhonium flagelliforme (Lodd.) Blume. Journal of Plant Biology 48: 25-31.

Devy, L. \& Sastra, D.R. 2012. Pengaruh radiasi sinar gamma terhadap kultur in vitro tanaman jahe. Jurnal sains dan teknologi Indonesia 8: 7-14.

Essai. 1985. Medicinal herbs index in Indonesia. Jakarta : PT Essai Indonesia.

Kadir, A. 2011a. Pengaruh iradiasi sinar gamma terhadap pembentukan tunas tanaman nilam. Journal agrivigor 10: 117-127.

Kadir, A. 2011b. Respon genotype dari padi mutan hasil iradiasi sinar gamma terhadap cekaman kekeringan. Journal agrivigor 10: 235-246.

Khatun, M.M, Khatun, H., Khanam, D. \&Al-Amin, M.D. 2010. In vitro root formation and plantlet development in dendrobium orchid. Bangladesh Journal of Agriculture Research 35(2): 257-265.

Karp, G. 2008. Cell and Molecular Biology - Concept and Experiment 5th Edition. USA : John Wiley \& Sons, Inc.

Khan, , I.A., Dahot, M.U., Seema, N., Yasmin, S., Bibi, S., Raza, S. \& Khatri, A. 2009. Genetic variability in sugarcane plantlets developed through in vitro mutagenesis. Pakistan Journal of Biotechnology 41(1): 153-166.

Kovacs, E. \& Keresztes, A. 2002. Effect of gamma and UV-B/C radiation on plant cells. Micron. 33 : 199-210.

Lai, C.S., Mas, R.HM.H, Naik, N.K., Majid, M.I.A., Mansor, S.M., and Navaratnam, V. 2008. Typhonium flagelliforme inhibits cancer cell growth in vitro and induces apoptosis: An evaluation by the bioactivity guided approach. Journal of Ethnopathology 118: 14-20.

Mishra, Y., Patel, P., Ansari, S.A. 2011. Acclimatization and macroproliferation of micropropagated plants of Bambusa tulda Roxb. Asian Journal of Experimental Biological Science 2(3): 498-501.

Mohan, S., Abdul, A.B., Abdelwahab, S.I., Al-Zubairi, A.S., Aspollah, Sukari, M., Abdullah, R., Taha, M.M., Beng, N.K. \& Isa, N.M. 2010. Typhonium flagelliforme inhibits the proliferation of murine leukemia WEHI-3 cells in vitro and induces apoptosis in vivo. Leukimia Research 34(11):1483-92.

Natawijaya, A., Afiyata A. \& Ritonga, A.W. 2009. Pengaruh Iradiasi Sinar Gamma terhadap Keragaan Planlet Tanaman Gloxinia. Skripsi. Program Studi Pemuliaan dan Bioteknologi Tanaman Departemen Agronomi dan Hortikultura. Sekolah Pasca Sarjana Institut Pertanian Bogor.

Nobakht, G.M., Kadir, M.A. \& Stanslas, J. 2009. In vitro mass propagation of Typhonium flagelliforme as affected by plant growth regulator. African Journal of Biotechnology 8(24): 6840-6843. 
Pospisilova, J., Ticha, I., Kadlecek, P., Haisel, D. \& Plzakova, Z. 1999. Acclimatization of micropropagated plants to ex vitro conditions. Biologia Plantarum, 42(4): 482-497.

Puchooa, D. \& Sookun, D. 2003. Induced mutation and in vitro culture of Anthurium andreanum. Food and agriculture research council 2003.

Purnamaningsih, R., Lestari, E.G., Syukur, M. \& Yunita, R. 2011. Evaluasi keragaman galur mutan Artemisia hasil iradiasi gamma. Jurnal IImiah Aplikasi Isotop dan Radiasi 6(2): 139-146.

Qosim, W.A. 2006. Studi iradiasi sinar gamma pada kultur kalus nodular manggis untuk meningkatkan keragaman genetik dan morfologi regeneran. Disertasi. Program Studi Agronomi, Sekolah Pascasarjana, Institut Pertanian Bogor.

Rohani, O., Kamal, S., Rajinder, S. \& Mohd-Nazir, B. 2012. Mutation induction using gamma irradiation on oil palm (Elaeis guineensis Jacq.) cultures. Journal of Oil Palm Research 24: 1448-1458.

Sianipar, N.F., Rustikawati., Maarisit, W., Wantho, A. \& Sidabutar, D.N.R. 2011. Embryonic calli induction, proliferation, and regeneration of rodent tuber plant (Typhonium flagelliforme Lodd.) by single node culture. International 58 Conference on Biological Science, Faculty of Biology, Universitas Gadjah Mada, pp. 80-88.

Sianipar, N.F., Wantho, A., Rustikawati, Maarisit, W. 2013. The effect of gamma irradiation on growth response of rodent tuber (Typhonium flagelliforme Lodd.) mutant in vitro culture. HAYATI Journal of Bioscience 20 (2): 51-56.

Sianipar, N.F., Maarisit, W., Valencia, A. 2013. Toxic activities of hexane extract and column chromatography fractions of rodent tuber (Typhonium flagelliforme Lodd.) on Artemia salina. Indonesian Journal of Agricultural Science 14(1): 1-7.

Sulistianingsih, R., Mangoendijojo, W., Purwantoro, A. \& Semiarti, E. 2006. Pengaruh irradiasi sinar gamma pada pertumbuhan plantlet anggrek bulan Phalaenopsis amabilis (L.) Bl. Risalah Seminar IImiah Aplikasi Isotop dan Radiasi.

Stampar, F., Hudina, M., Usenik, V., Sturm, K., Marn, V.M. \& Batic, F. 1999. Influence of leaf area on net photosynthesis, yield, and flower-bud formation in apple (Malus domestica Borkh.) Plant Physiology 39(3): 101-106.

Syahid, S.F. 2008, Keragaman morfologi, pertumbuhan, produksi, mutu dan fitokimia keladi tikus (Typonium flagelliforme Lodd.) blume asal variasi somaklonal. Jurnal Littri 14(3):113-118.

Syahid, SF \& Kristina, NN. 2007. Induksi dan regenerasi kalus keladi tikus (Typhonium flagelliforme. Lodd.) secara in vitro. Jurnal Littri, 13(4): 142-146.

Teale, W.D., Papanov, I.A., Ditengou, F. \& Palme, K. 2004. Auxin and the developing root of Arabidopsis thaliana. Physiologia Plantarum 123: 130-138.

Wegadara, M. 2008. "Pengaruh Iradiasi Sinar Gamma pada Buah terhadap Keragaan Tanaman Anthurium (Anthurium andreanum). Skripsi. Program Studi Pemuliaan dan Tanaman dan Teknologi Benih. Fakultas Pertanian Institut Pertanian Bogor. 